\title{
Common pathways by which non-native forest insects move internationally and domestically
}

Nicolas Meurisse, $1 \square$

Email nicolas.meurisse@scionresearch.com

Davide Rassati, 2

Email davide.rassati@unipd.it

Brett P. Hurley, 3

Email brett.hurley@fabi.up.ac.za

Eckehard G. Brockerhoff, 4

Email eckehard.brockerhoff@scionresearch.com

Robert A. Haack, 5

Emailrhaack@fs.fed.us

1 Scion (New Zealand Forest Research Institute), 49 Sala Street, Private Bag 3020, Rotorua, 3046 New Zealand

2 Department of Agronomy, Food, Natural Resources, Animals and Environment

(DAFNAE), University of Padua, Viale Dell'Università, 16, 35020 Legnaro, Italy

3 Department of Zoology and Entomology, Forestry and Agricultural Biotechnology Institute (FABI), University of Pretoria, Pretoria, 0002 South Africa

4 Scion (New Zealand Forest Research Institute), 11 Kyle Street, P.O. Box 29-237, Christchurch, 8440 New Zealand

5 Emeritus, US Department of Agriculture, Forest Service, Northern Research Station, 3101 Technology Blvd., Suite F, Lansing, MI, 48910 USA

\section{Abstract}

International trade and movement of people are largely responsible for increasing numbers of non-native insect introductions to new environments. For forest insects, trade in live plants and transport of wood packaging material (WPM) are considered the most important pathways facilitating long-distance invasions. These two pathways as well as trade in firewood, logs, and processed wood are commonly associated with insect infestations, while "hitchhiking" insects can be moved on cargo, in the conveyances used for transport (e.g., containers, ships), or associated with international movement of passengers and mail. Once established in a new country, insects can spread domestically through all of the above pathways. Considerable national and international efforts have been made in recent years to reduce the risk of international movement of plant pests. International Standards for Phytosanitary Measures (ISPMs) No. 15 (WPM), 36 (plants for planting), 
and 39 (wood) are examples of phytosanitary standards that have been adopted by the International Plant Protection Convention to reduce risks of invasions of forest pests. The implementation of ISPMs by exporting countries is expected to reduce the arrival rate and establishments of new forest pests. However, many challenges remain to reduce pest transportation through international trade, given the ever-increasing volume of traded goods, variations in quarantine procedures between countries, and rapid changes in distribution networks. It is therefore likely that many more humanassisted invasions of forest insects will take place. New geographic expansions by natural modes are also made possible due to changes in host distribution and/or climate.

\section{Keywords}
Biological invasions
Global change
Globalization
Invasion pathways
ISPM
Phytosanitary policy

Communicated by J. D. Sweeney.

Special Issue on Invasive Pests of Forests and Urban Trees.

\section{Electronic supplementary material}

The online version of this article (https://doi.org/10.1007/s10340-018-0990-0) contains supplementary material, which is available to authorized users.

\section{Key message}

- Rapid increases in globalization and international trade have inadvertently led to higher arrival rates of non-native forest insects in countries worldwide. Forest insects can be transported to new countries via several pathways including trade in live plants, wood-based items, hitchhiking on non-wood items and in international mail, or movement by natural dispersal.

- We review several important pathways that contribute to pest introductions to new areas, focusing on forest insects and their associated phytosanitary policies.

\section{Introduction}

Increasing international trade and globalization have led to increasing risk of non-native organism introductions via sea, air, and land pathways (Levine and D'Antonio 2003; Brasier 2008; Westphal et al. 2008; Hulme 2009; Seebens et al. 2017). The vast majority of international trade is carried by ships (IMO 2012). Since 1980, world maritime freight trade volumes have grown about threefold, to reach about 10 billion tonnes in 2015 (UNCTAD 2017). Air transport volumes are much lower, with about 50 million tonnes of air cargo transported annually (ICAO 2016). Passenger flights have also witnessed a very strong increase, approximately 400-fold between 1945 and 2015 (IATA 2017). Each year, about 35 million flights transport 3.5 billion passengers over a network of about 51,000 routes, which are predicted to double again by 2035 (IATA 2017). 
In this context, historical accumulation curves of non-native species introductions show no sign of saturation (Brockerhoff and Liebhold 2017; Seebens et al. 2017), highlighting that improved phytosanitary practices struggle to stem the increase in pathway volumes (Saccaggi et al. 2016). This situation is also worsened by the concurrent increasing domestic movement of goods and people which can contribute to range expansion of both native and introduced species (Rassati et al. 2018). Transport data from the Organisation for Economic Co-operation and Development (OECD) show that road and rail are predominant modes for both freight and passenger transportation in most countries (ITF 2017).

Insects are particularly prominent invaders of new environments worldwide (Liebhold et al. 2016), with most being easily transported unintentionally by international movement of goods and people. Compared to other modes of transportation, shorter travel times over long distances lead to increased risk of moving live organisms between continents. Thousands of forest insect species have invaded new areas (Aukema et al. 2010; Liebhold et al. 2017) with some causing massive ecological and economic impacts. For instance, emerald ash borer (Agrilus planipennis; Buprestidae) introduced to North America from Asia in the 1990s has killed millions of ash trees (Fraxinus) with economic impacts in the billions of dollars (Kovacs et al. 2011; Haack et al. 2015). In comparison, few beneficial insects are introduced to new areas (Brockerhoff and Liebhold 2017). These are generally pollinators and biocontrol agents established intentionally (Donovan 1980; Kenis et al. 2017).

International movement of live plants and wood packaging material (WPM) are considered the most important pathways for forest insect invasions (Brasier 2008; Liebhold et al. 2012; Eschen et al. 2015a). Many other insects travel as hitchhikers without infesting commodities or packaging directly, but rather being transported on the cargo or within the "vessels" used for conveyance, such as packaging, shipping containers, ships, aircraft, vehicles, and machinery (Toy and Newfield 2010). In this paper, we discuss these and other pathways that facilitate entry or spread of insects both internationally and domestically, including trade in logs, firewood, processed wood, passenger baggage, and international mail. We also consider natural modes of geographic expansion by active dispersal or passive transportation.

\section{Live plants, cuttings and seeds}

Importation of live plants is an important pathway for the introduction of non-native insects (Smith et al. 2007; Brasier 2008; Hulme et al. 2008; Roques 2010; Liebhold et al. 2012). Live plants are often referred to as "plants for planting" (FAO 2011), imported in many forms including rooted and unrooted plants for retail and propagation, bonsai, bulbs, and budwood, which are dormant cuttings for propagation (Liebhold et al. 2012). Cut flowers, ornamental foliage, and seeds, which are also transported in large volumes, are additional potential pathways for forest insects but will not be addressed in detail here (Areal et al. 2008; Auger-Rozenberg and Boivin 2016; Lee et al.

2017).

The most common forest insects moving on "plants for planting" are Homoptera and Thysanoptera (Roques and Auger-Rozenberg 2006; Liebhold et al. 2012; Tables 1-2; Fig. 1). Pests in many other orders move on live plants, including Coleoptera [e.g., Anoplophora chinensis (Cerambycidae, citrus longhorned beetle; Haack et al. 2010a), Callidiellum rufipenne (Cerambycidae, Japanese cedar longhorned beetle; Cocquempot 2007), Xylosandrus morigerus (Scolytinae, brown twig beetle; Kirkendall and Faccoli 2010], and Lepidoptera [Epiphyas postvittana (Tortricidae, light brown apple moth; Venette et al. 2003)]. 
Table 1

Percent of insect interceptions made at ports-of-entry in various countries by insect order and pathway

Insect order ${ }^{\mathrm{a}}$ Importing country and commodities inspected

\begin{tabular}{|c|c|c|c|c|c|c|c|c|}
\hline & \multicolumn{4}{|l|}{ USA } & \multirow{2}{*}{$\begin{array}{l}\text { Australia } \\
\text { Empty } \\
\text { containers }\end{array}$} & \multirow{2}{*}{$\begin{array}{l}\text { Chile } \\
\text { WPM }\end{array}$} & \multicolumn{2}{|c|}{ EPPO ( 29 coun } \\
\hline & $\mathrm{All}^{\mathrm{b}}$ & $\begin{array}{l}\text { Live } \\
\text { plants }\end{array}$ & Wood & $\begin{array}{l}\text { Airline } \\
\text { baggage }\end{array}$ & & & All $^{\mathrm{c}}$ & Bonsai \\
\hline Coleoptera & 12.8 & 4.9 & 91.7 & 11.9 & 46.2 & 84.6 & 17.8 & 2.5 \\
\hline Collembola & 0.03 & 1.5 & 0.01 & 0.01 & 0.05 & & & \\
\hline Dermaptera & & & & & 1.0 & 0.4 & & \\
\hline Diptera & 20.4 & 1.2 & 0.3 & 21.6 & 30.3 & 1.6 & 30.7 & \\
\hline Embioptera & & & & & 0.04 & & & \\
\hline Ephemeroptera & & & & & 0.03 & & & \\
\hline Heteroptera & 3.9 & 3.8 & 3.1 & 1.3 & 2.6 & 0.9 & 0.3 & \\
\hline Homoptera & 36.5 & 53.3 & 0.3 & 49.5 & & 0 & 30.0 & 84.7 \\
\hline Hymenoptera & 0.4 & 0.8 & 1.6 & 0.2 & 7.0 & 8.5 & 0.6 & 6.1 \\
\hline Isoptera & 0.1 & 0.06 & 1.3 & 0.04 & 1.2 & 1.6 & & \\
\hline Lepidoptera & 20.7 & 7.5 & 1.4 & 15.5 & 5.8 & 1.1 & 9.3 & 0.4 \\
\hline Neuroptera & & & & & 0.2 & 0.2 & & \\
\hline Odonata & & & & & 0.01 & & & \\
\hline Orthoptera & 0.9 & 7.5 & 0.3 & 0.09 & 4.9 & 0.9 & 0.2 & \\
\hline Psocoptera & & & & & 0.5 & 0.3 & 0.07 & \\
\hline Siphonaptera & & & & & 0.01 & & & \\
\hline Thysanoptera & 4.4 & 19.27 & 0.08 & & 0.03 & & 11.1 & 6.4 \\
\hline Thysanura & & & & & 0.2 & & & \\
\hline $\begin{array}{l}\text { Total number } \\
\text { of } \\
\text { interceptions }\end{array}$ & 577,343 & 17,758 & 7896 & 289,890 & 7426 & 1053 & 6734 & 281 \\
\hline Years & 1985-2001 & 2003-2010 & $1985-2001$ & 1984-2000 & 1996 & 1995-99 & 1995 & 2004 \\
\hline Reference & $\begin{array}{l}\text { Haack } \\
(2001)\end{array}$ & $\begin{array}{l}\text { Liebhold } \\
\text { et al. } \\
(2012)\end{array}$ & $\begin{array}{l}\text { Haack } \\
(2001)\end{array}$ & $\begin{array}{l}\text { Liebhold } \\
\text { et al. } \\
\text { (2006) }\end{array}$ & $\begin{array}{l}\text { Stanaway } \\
\text { et al. } \\
\text { (2001) }\end{array}$ & $\begin{array}{l}\text { Beéche- } \\
\text { Cisternas } \\
(2000)\end{array}$ & $\begin{array}{l}\text { Roque } \\
\text { Rozen }\end{array}$ & $\begin{array}{l}\text { S and Auq } \\
\text { berg }(200\end{array}$ \\
\hline
\end{tabular}

${ }^{a}$ Orders reflect older taxonomy used by many countries in past decades. Some data were reassigned to make all $\mathrm{rc}$ equivalent. Heteroptera refers to the "true bugs" formerly classified as the order Hemiptera. Homoptera refers to three current suborders Auchenorrhyncha, Sternorrhyncha, and Coleorrhyncha. The order Orthoptera includes $\mathrm{Ph}$ and Blattodea (but not termites)

${ }^{b}$ The term "all" means the complete dataset of insect interceptions made at US ports-of-entry and border crossing including baggage, cargo, and conveyances

${ }^{\mathrm{c}}$ These data include all interceptions listed in the "EPPO Reporting Service" for non-native species and the assoc pathway (e.g., bonsai, plants for planting, seeds, vegetables, wood packaging, etc.) 


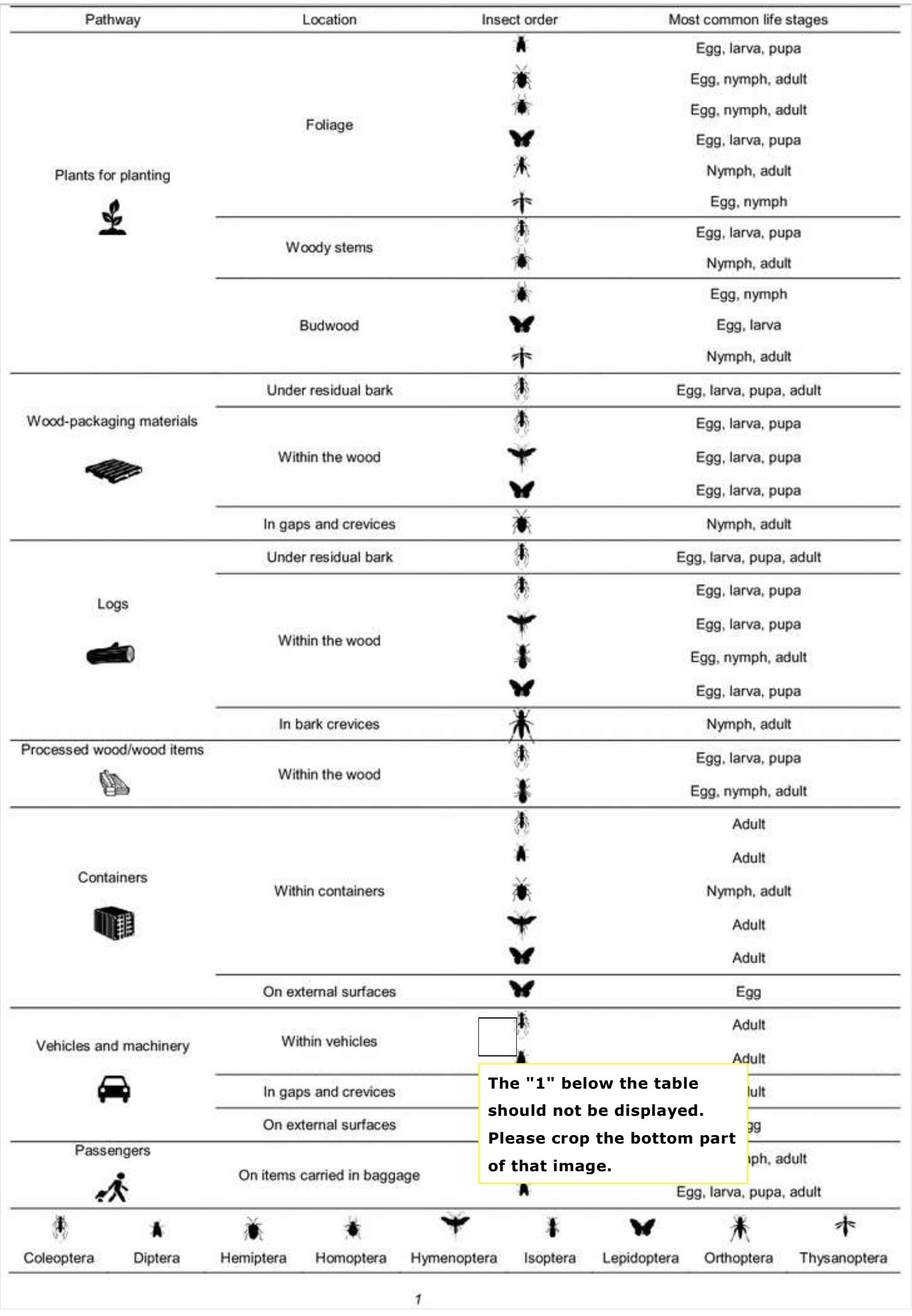

Table 2

Summary details for the most common insects (by order and life stage) to be intercepted at ports by pathway and substrate or plant part 
Figure 1. Relative frequency of insect orders unintentionally transported on common pathways. The size of the circle denotes the relative importance of each insect order within each pathway, based on interceptions at ports-of-entry (MAF 2003; Caton et al. 2006; Liebhold et al. 2006; Table 1) and informed estimates. Large circle $=$ common; medium circle $=$ occasional; small circle $=$ rare. Heteroptera refers to the "true bugs" formerly classified as the order Hemiptera. Homoptera refers to the three current suborders Auchenorrhyncha, Sternorrhyncha, and Coleorrhyncha. The order Orthoptera includes Phasmida and Blattodea (but not termites). Live plants = live plants, cuttings, and seeds; Logs = wood traded as logs and which can be used for various purposes such lumber, pulp, or fuel; Wood packaging=blocks, dunnage, crating, pallets, skids, cases, and drums; Processed wood = sawn timber and other processed bulk wooden and flooring; Containers = containers, cargo, sea and air vessels, and land modes of transport. Vehicles = trade, vehicles, and machinery; Passengers=passengers themselves, their luggage, and personal effects

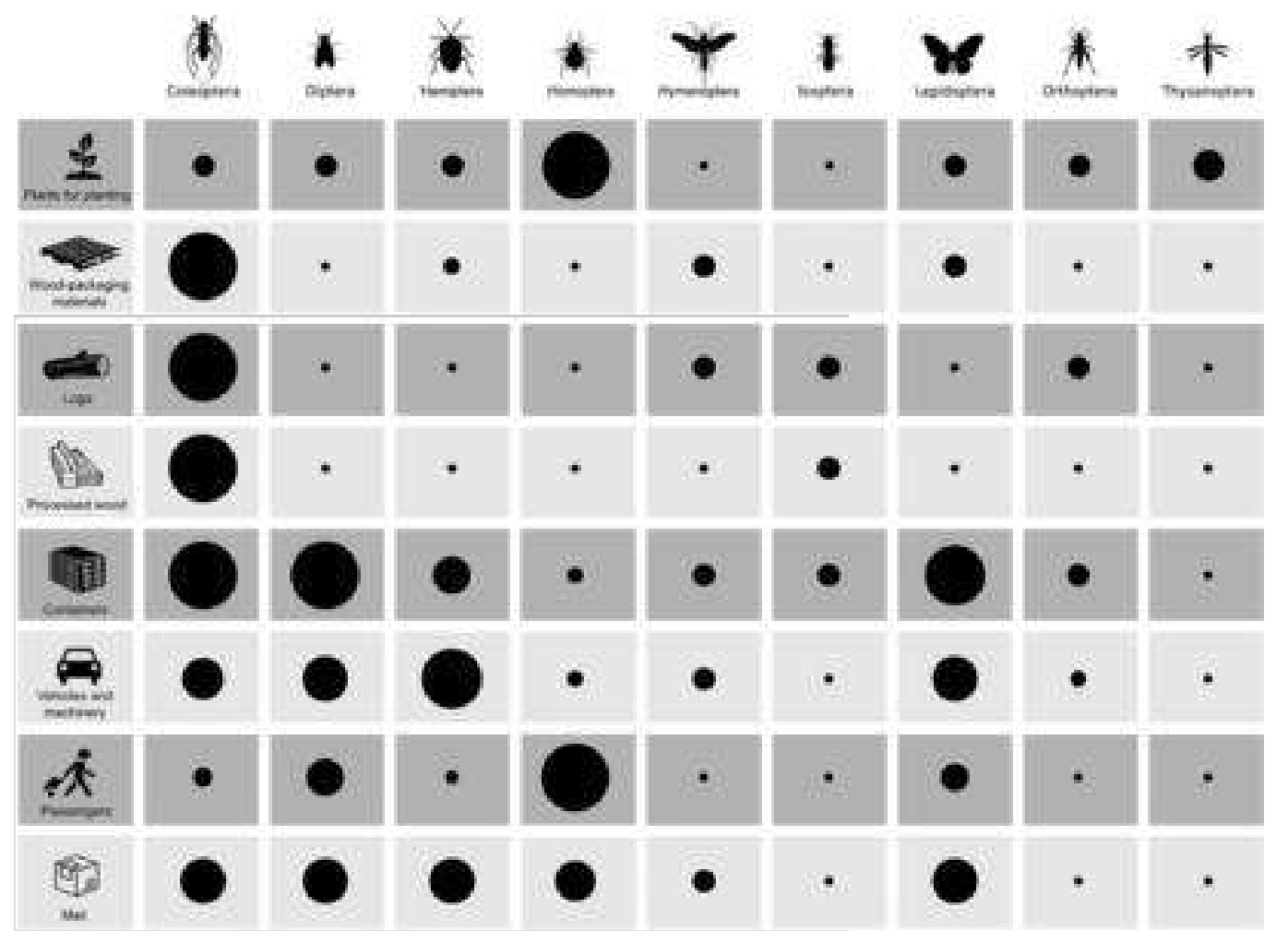

Different forms of live plants can host pests; for example, budwood for propagation was found to host scale insects, Lepidoptera larvae, and thrips in South Africa (Saccaggi and Pieterse 2013), and similarly budwood was the likely pathway through which the Oriental chestnut gall wasp, Dryocosmus kuriphilus (Cynipidae), entered the USA (Rieske 2007). A large majority of interceptions on bonsai plants traded from Asia to European countries are Homoptera (Table 1). Bonsai plants have also been shown to be a source of Anoplophora longhorned beetles in both Europe and USA (Haack et al. 2010a; Eyre and Haack 2017). Trade in live plants is also considered one of the main pathways for introduction of gall-forming insects of forest trees (Csóka et al. 2017).

Ornamental plants are usually considered the most high-risk form of live plants for moving insects because (1) they are transported swiftly, promoting high insect survival even when large distances are involved (Smith et al. 2007; Colunga-Garcia et al. 2013); (2) the trade volume of ornamentals is increasing worldwide (Eschen et al. 2015a); (3) they tend to be planted outdoors (Liebhold et al. 2012), promoting establishment (van der Gaag et al. 2017); (4) they are often transported with soil or growing media, facilitating transfer of soil-borne insects and pathogens (Migliorini et al. 2015); and (5) fashion trends in garden plants change rapidly (Smith et al. 2007) along with related markets (Liebhold et al. 2012), leading to high turnover in the plant species imported (Eschen et al. 2017). In the EU, for 
example, the pool of non-native plants in gardens and parks is over 16,000 species, representing over 200 plant families from nearly every continent (Niinemets and Peñuelas 2008).

\section{Wood packaging material (WPM)}

WPM is an ideal medium for transporting bark- and wood-boring insects, given that it is normally made from recently cut trees and often has some residual bark (Allen and Humble 2002, Eyre et al. 2018). Thousands of insect species occur worldwide that develop in tree bark and wood, infesting living, dying, and dead trees, as well as moist, dry, and decaying wood (Haack and Slansky 1987; Haack 2017). Larval development times also vary widely among borers, lasting a few weeks or months in most species but multiple years in others (Haack and Slansky 1987; Haack et al. 2017). WPM items such as pallets can be repaired and reused and thereby consist of wood from multiple countries that can differ in their phytosanitary treatments (Clarke et al. 2001; Gu et al. 2006). Furthermore, WPM is used with both agricultural and non-agricultural products and can be fabricated as blocks, dunnage, crating, pallets, skids, cases, and drums (Meissner et al. 2009). WPM was the likely pathway for the introduction of several bark- and wood-infesting insects such as Agrilus planipennis (Haack et al. 2015), Anoplophora glabripennis (Cerambycidae, Asian longhorned beetle; Haack et al. 2010a), Ips grandicollis (Scolytinae, eastern five-spined engraver; Morgan 1967), and Sirex noctilio (Siricidae, sirex woodwasp; Hoebeke et al. 2005).

WPM is more commonly associated with maritime than air shipments. For example, about $75 \%$ of maritime shipments entering the USA contained WPM compared with 33\% of air shipments (Meissner et al. 2009). Similarly, in New Zealand, $40 \%$ of maritime shipping containers arrived with WPM, of those $13.4 \%$ contained bark (MAF 2006). Military transports also commonly involve the use of WPM, and a case of such WPM being implicated in the invasion of a pine pathogen from the USA to Italy was described by Garbelotto and Gonthier (2013). Given the volume of WPM shipped, it is not surprising that insects are commonly intercepted in WPM at ports-of-entry worldwide. Most insects intercepted on WPM were beetles (Coleoptera; Tables 1-2; Fig. 1), for example, about $92 \%$ in the USA (Haack 2001), and nearly 85\% in Chile (Beéche-Cisternas 2000). At the family level, most intercepted beetles on WPM were Cerambycidae and Scolytidae (now Scolytinae) (Table S1 in Supplementary Material; Brockerhoff et al. 2006). Other insect orders reported on WPM with important families of wood-boring species include Hymenoptera (Siricidae) and Lepidoptera (Cossidae and Sesiidae) (Tables 1-2; Fig. 1). Besides borers, many other insect species are found in WPM, including predators and parasitoids (Beéche-Cisternas 2000). For example, more than 2500 adult insects were reared from spruce (Picea) logs used to brace shipments of granite blocks from Norway to Canada, representing over 40 species, including bark beetles (6 spp.), wood borers (10), and associated parasitoids (>12), predators (4), and scavengers (>12) (Humble and Allen 1999).

\section{Logs (roundwood)}

Large volumes of logs are transported worldwide and used for lumber, veneer, pulp, and fuel (FAO 2011). Worldwide log exports in 2014 were 133.5 million $\mathrm{m}^{3}$ for industrial roundwood and 9.3 million $\mathrm{m}^{3}$ for fuelwood (Allen et al. 2017). During 1996-2009, the USA imported fuelwood from 34 countries that was delivered to 27 US states (Haack et al. 2010b). Logs are generally considered a high-risk pathway (Tkacz 2002; Kliejunas et al. 2006). However, the level of risk associated with log imports depends on multiple factors including the area of origin, the tree species, or the application of specific phytosanitary treatments such as debarking, in-transit fumigations, or seasonal restrictions to transport (USDA APHIS 2010; FAO 2011). 
In some countries, such as Canada and the USA, firewood can be transported over long distances by people when driving to recreational sites such as campgrounds (Haack et al. 2010b; USDA APHIS 2010; Jacobi et al. 2011). As with logs, firewood is often untreated, has residual bark, and is stored for long periods before used, and therefore also considered a high-risk pathway for pests (USDA APHIS 2010; FAO 2011).

Many species of forest insects and other invertebrates have been intercepted on imported roundwood logs (Bain 1977; Haack 2006; Eyre and Haack 2017). In Finland, Siitonen (1990) recovered several borer species from coniferous logs imported from Russia, including 23 scolytine species. Similarly, log exports from the USA to China introduced two species of Dendroctonus (Scolytinae), one of which (D. valens, red turpentine beetle) has become a major pest on pines (Pinus) in China (Ciesla 1992; Yan et al. 2005). The cerambycids Phoracantha semipunctata and P. recurva have colonized several Eucalyptus-growing regions worldwide, likely being introduced in pulpwood logs (Rassati et al. 2016). In addition, domestic movement of Larix logs for home construction in the USA was the likely pathway for movement of the western scolytine Dendroctonus pseudotsugae (Douglas-fir beetle) to the eastern USA (Dodds et al. 2010). It is also important to consider illegal trade of logs and other wood products, given that such items could enter a country without treatment or inspection and thus pose a phytosanitary risk (Bisschop 2012).

As with logs, many insects and other invertebrates can be moved in firewood. For example, in Tasmania, Todd and Horwitz (1990) reported that Eucalyptus firewood contained worms, spiders, crustaceans, millipedes, centipedes, and insects (eight orders; mostly Coleoptera and Hymenoptera). In the western USA, a survey of untreated firewood obtained from several retail outlets found live insects in $47 \%$ of individual firewood bundles, primarily Scolytinae and other insects representing nine orders (Jacobi et al. 2012). In Michigan, Haack et al. (2010b) reported that 23\% of individual pieces of firewood transported by the public contained live wood borers (representing at least seven families in three orders; $;$, mostly Cerambycidae and Scolytinae), and an additional $41 \%$ of the firewood pieces had evidence of previous borer infestation. Firewood has been implicated as the likely pathway by which several important bark- and wood-feeding insects have been moved within the USA, such as Agrilus planipennis (Cappaert et al. 2005; Haack et al. 2015), Anoplophora glabripennis (Haack et al. 2010a), and Xyleborus glabratus (Scolytinae, redbay ambrosia beetle; Cameron et al. 2008; Haack et al. 2010b). Species that would normally associate with live plants, but have a propensity to shelter in dark gaps and crevices, can also be transported long distances on logs or firewood. In Canada, the beech leaf-mining weevil Orchestes fagi (Curculionidae) overwinters under bark of beech and other non-host trees, facilitating long-distance movement if infested logs or firewood are transported during this period (Morrison et al. 2017).

\section{Wood chips}

International movement of wood chips, defined as wood reduced to small pieces that can be used for pulping, fiberboard production, and fuel, represents a potential pathway for bark- and wood-infesting insects (Kopinga et al. 2010; Allen et al. 2017). Global trade in wood chips is growing quickly, with East Asia (China, Japan, and Korea) and Europe being major importers, and Southeast Asia, South America, and Oceania major exporters (Jiang et al. 2017).

Although no established populations of non-native bark- and wood-infesting insects have been traced to wood chips, there is concern for this possibility, especially in Europe where large volumes of wood chips are imported for renewable energy production (Flø et al. 2014). The chipping process usually results in high mortality of borers, but some individuals can survive, especially when the insects are 
small (e.g., scolytines) relative to chip size (McCullough et al. 2007; Eatough Jones and Paine 2015).

\section{Processed wood and other wood items and cones}

Many other types of wood items can serve as pathways for insects, especially borers. The phytosanitary risk of some of these wood items is well recognized, such as lumber with residual bark, while for others the risk is less obvious, for example, decorative items such as Christmas items comprising wooden parts or cones. The bark- and wood-infesting insects intercepted in lumber are basically the same as those reported above for wood packaging, firewood, and logs (Bain 1977; Haack 2006). Even when lumber is treated properly, some borers can successfully infest post-treatment, especially when residual bark is present (Evans 2007; Haack and Petrice 2009). In New Zealand, about $11 \%$ of bark and wood borer interceptions were from sawn timber, $7 \%$ from logs and other bulk wooden material, and about $2 \%$ from wooden cargo (e.g., wooden sport items, furniture, and handicrafts; Ridley et al. 2000). However, as the majority of raw wood imported into the country is sawn timber, these numbers reflect the traded volumes rather than actual infestation rates.

Infested wood can be used inadvertently in the construction of buildings, furniture, and flooring, with some adult borers emerging years after manufacture (Cocquempot and Lindelöw 2010; Haack 2017). Low-quality wood, occasionally infested with borers, can be placed inside upholstered furniture and therefore difficult to detect (Eyre and Haack 2017). At times the paperwork associated with imported products falsely indicates that no wood is present. This was the case with imported "artificial Christmas trees" from China to the USA when it was discovered that the trunk portion was real wood with bark from Cryptomeria trees, which were often infested with Callidiellum cerambycid species (Maier 2017). Another example involves pine cones from India imported to the USA for use in handicrafts and potpourri mixtures that were infested with the cerambycid Chlorophorus strobilicola and tortricid seed-feeding moths in the genus Cydia (Kiesz 2003).

\section{Contaminated non-wood items transported as cargo}

Cargo items contaminated with hitchhiking forest insects could include anything from forestry machinery and equipment to camping equipment (Ridley et al. 2000; Withers 2001). Although monitoring of this pathway is less common, its importance should not be underestimated.

Cargo transported on airplanes has the shortest travel times relative to distance travelled; hence, this is considered to be a particularly effective pathway leading to introductions by hitchhiking species (McCullough et al. 2006). For instance, 158 insect pest species across 33 families and five orders were intercepted on cargo aircraft from 730 flights at Miami International Airport (Caton et al. 2006), and Lepidoptera and Coleoptera were the dominant orders. Air cargo contamination was most prevalent during the wet seasons (when pests are generally more abundant) and night-time loading operations (when airport lighting attracts insects) (Caton et al. 2006).

\section{Containers, used vehicles, and machinery}

Hitchhiking insects are regularly found in shipping containers. Most are agricultural pests, but some significant forest pests are occasionally found (Table 1; Fig. 1). Given the large volumes of containers transported worldwide, even relatively low contamination rates represent a significant risk. In Australia, a survey of 3001 empty containers showed $39 \%$ were internally contaminated with live and dead insects; 176 containers $(5.9 \%)$ had live individuals, including one scolytine (Stanaway et al. 2001; Table 1). In New Zealand, a survey of 11,265 containers arriving at ports found live insects in $4.1 \%$ of loaded containers and 3.6\% of empty containers (MAF 2003). Of 173 live insects identified in the above survey, there were 15 Coleoptera species, two Hemiptera, three Hymenoptera (all ants), and 
four Psocoptera. Forest insects included one live bostrichid powderpost beetle (Sinoxylon sp.) (MAF 2003). In a similar survey at the port of Auckland, New Zealand, contamination rates by live insects were $7.4 \%$ internally and $0.4 \%$ externally in loaded containers, compared with $3 \%$ internally and no record externally in empty containers (MAF 2006). Dead individuals of significant forest pests were also found, including one ambrosia beetle (Xyleborus sp.; Scolytinae) and one larval gypsy moth (Lymantria dispar; Erebidae). In the above two surveys, little external contamination was reported ( $0.1 \%$ overall), which may reflect the fact that only the four lateral sides of each container were inspected. By contrast, Gadgil et al. (2000) examined the six external sides of 3681 containers imported to New Zealand and found live insects externally on 5\% of inspected containers, either as adults or immature stages. Forest pests included four bag moths (Psychidae), and one gypsy moth egg mass. Of the dead individuals, 49 were from insect groups with potential to become tree pests, including termites, cicadas, longhorned beetles, and weevils.

Species that have a propensity to shelter in dark gaps and crevices, or that have pupae or eggs that may be affixed to steel surfaces, are particularly prone to transportation by containers. These include adults of the brown marmorated stink bug, Halyomorpha halys (Pentatomidae), which was probably introduced to North America as a hitchhiker with shipping containers from Asia (Hoebeke and Carter 2003), and the painted apple moth, Teia anartoides (Erebidae), which was presumably introduced from Australia to New Zealand as eggs attached externally to sea containers (Harris 1988).

Many Lepidoptera have behaviors that allow them to be associated with objects other than host plants, especially during the egg or pupal stages. For example, adult female Asian gypsy moth, Lymantria dispar, are attracted to artificial lights in ports, where they may lay egg masses on the surfaces of containers, vehicles, vessels, and other cargo (Schaefer and Strothkamp 2014). Interceptions of gypsy moth egg masses on ships and their containers are frequent in North America and Australasia (Gray 2017). In New Zealand, for example, 22 gypsy moth egg masses were found on containers during 1995-1997, arriving from Russia, Hong Kong, and Japan (Newfield 2008). Because of the difficulties to detect egg masses on containers, likely many more enter undetected.

As for shipping containers, species that have the ability to colonize gaps and crevices on manmade equipment, or affix as eggs or pupae to steel surfaces of vehicles and machinery, are more likely to remain hidden and protected and undetected during transport. Colonization is more likely on used cars, trucks, or farm and forestry machinery, which is typically kept outdoors for long periods. Records in New Zealand showed that most (38.5\%) brown marmorated stink bug interceptions were on used and new vehicles, especially at a time of the year when adults are looking for shelter in their area of origin (Brockerhoff et al. 2016; Catherine Duthie, pers. comm.).

\section{Marine and air vessels, and land modes of transport}

Hitchhiking insects are increasingly reported associated with various modes of transportation (planes, ships, trucks, vehicles, and trains) and with containers and cargo items (Fig. 1). The Asian gypsy moth has triggered much attention worldwide as a potential hitchhiker due to frequently finding its egg masses on sea vessels (see also section on "Containers"). For instance, the superstructure of $6 \%$ of 478 inspected sea vessels arriving in Australia from high-risk Asian ports was carrying gypsy moth egg masses, with a total of 514 egg masses (Nielsen et al. 2013). When ships are close to land, neonate larvae can balloon to shore on spun silken threads and settle on suitable host plants (Zlotina et al. 1999).

Reports of hitchhiking pests on land modes of transports are generally less well documented. Occasional reports are made of insects entering vehicles on people's clothing or hair, or flying in and 
out of vehicles and trailers [e.g., for the bronze bug Thaumastocoris peregrinus (Thaumastocoridae) in New Zealand (NM, pers. obs.) and South Africa (BPH, pers. obs.)]. Similar observations have been made for Agrilus planipennis in North America (Buck and Marshall 2009; RAH, pers. obs.).

\section{Travelers with personal baggage and food items}

Travelers can also inadvertently transport forest insects between countries. In New Zealand and Australia, where most international travelers arrive by air, national phytosanitary authorities inform incoming passengers about biosecurity concerns and that systematic baggage inspection will be conducted, often involving X-ray scanning and sniffer dogs. A recent baggage survey of 6816 passengers entering New Zealand at international airports showed 3\% of travelers carried fresh or dry plant products (MPI 2013). Travelers often carried food items such as fresh fruits, which can be contaminated with a variety of agricultural insect pests, while only a few articles of baggage contained nursery stock, wood items, or other plant items that are more likely to be associated with forest species. In the same survey (MPI 2013), there were 127 discoveries of improperly cleaned camping and hiking gear, which can introduce non-native species to recreation areas (Anderson et al. 2015). For instance, Gadgil and Flint (1983) found live insects (including forest species), in six out of 45 tents accompanying passengers arriving in New Zealand.

Analysis of US insect interception data with passenger baggage arriving mostly by air during 1984-2000 showed that most insects were associated with fresh plant items, either for consumption, propagation, or other plant parts (McCullough et al. 2006). About 1\% of baggage interceptions were not directly associated with any sort of material (i.e., hitchhikers), and less than $0.1 \%$ of baggage interceptions were associated with wood material. Most insects intercepted on air baggage entering the USA during this 17-year period were Homoptera in the suborders Sternorrhyncha, Auchenorrhyncha, or Coleorrhyncha, followed by Diptera, Lepidoptera, and Coleoptera (Liebhold et al. 2006; Tables 1-2; Fig. 1).

\section{Contaminated mail and packages}

Contaminated courier mail and packages is a less obvious and less well-documented pathway for forest insect introductions. Examples of mailed items that could harbor forest insects include wooden ornaments/gifts, wood blocks for carving, fresh or dried plant parts, and seeds (GISTF 2017). In Fig. 1, we considered the types of insects commonly associated with mail to be similar to those intercepted in passenger baggage (Table 1; Liebhold et al. 2006).

Insects can also be transported intentionally by mail. Introductions of beneficial insects such as pollinators or biological control agents are usually strictly regulated and therefore are expected to have little or no adverse effects (Brockerhoff and Liebhold 2017). On the other hand, there are several historical examples of unintended escapes of insects followed by establishment in the natural environments, notably from pet trade or exhibits, or from rearing/production facilities (Kumschick et al. 2016). For example, the Australian Eucalyptus-feeding stick insect Extatosoma tiaratum (Phasmatidae) is exported as an insect pet to many countries such as South Africa, where Eucalyptus is grown commercially (Hurley et al. 2016). Insects purchased as pets are often carelessly discarded in gardens or fields, thus providing an opportunity for their establishment.

\section{Natural dispersal}

For non-native insects, geographic expansion usually follows human-assisted movement into a new region. In recent history, however, there are examples where native and non-native forest insects have significantly expanded their geographic ranges naturally (i.e., not human-assisted). These are usually 
in relation to major changes in host distribution and/or climate. For instance, the progressive southern and western expansion of two European spruce-infesting scolytines (Dendroctonus micans and Ips typographus) and their natural enemies have followed the expansion, essentially during the nineteenth century, of spruce plantations from southwestern Eurasia (Mayer et al. 2015). Increasing temperatures have also facilitated range expansion in some forest insects, especially at higher latitudes and elevations. In Europe, higher winter temperatures have increased larval survival and nocturnal adult dispersal of the pine processionary moth, Thaumetopoea pityocampa (Thaumetopoeidae), allowing northern expansion (Battisti et al., 2006). Similarly, in North America, warmer temperatures have allowed the mountain pine beetle, Dendroctonus ponderosae (Scolytinae), to spread northward in Canada and cross the Rocky Mountains, thereby threatening pines in the East (Carroll et al. 2003).

In these examples, the mode of dispersal is either adult active flight or passive transportation, usually supported by wind currents. Although not as common as range expansion over land, there are also reports of natural dispersal of insects across oceans. The aerial movement of insects from Australia to New Zealand by means of the trans-Tasman airstreams is a common occurrence (Close et al. 1978). New Zealand lies approximately $1800 \mathrm{~km}$ downwind from Australia, and a number of small insects, such as aphids, but also Lepidoptera, have been introduced to New Zealand by these air currents (Close et al. 1978; Fox 1978; Hoare 2001), although most have not established. Australia is the native range of Eucalyptus trees, and their associated herbivorous insects, and thus wind-assisted introductions of eucalypt insect pests are a potential threat to Eucalyptus plantations in New Zealand (Withers 2001). Natural rafts can also provide insects, including xylophagous beetles, the means to cross oceans. Logs from the Amazon have been recorded as far as $1600 \mathrm{~km}$ from the coast (Holzapfel and Harrell 1968). Another form of natural dispersal is when insects are vectored by another animal species (excluding humans), such as birds and mammals. For example, birds in North America help disperse the hemlock woolly adelgid, Adelges tsugae (Adelgidae; McClure 1990).

\section{Policy and management}

There have been strong global efforts in recent years to reduce the risk of international movement of plant pests by the pathways discussed here. The International Plant Protection Convention (IPPC) is the main organization that sets global standards for plant health (Allen et al. 2017; Ormsby and Brenton-Rule 2017). As of April 2018 the IPPC had 41 adopted standards known as International Standards for Phytosanitary Measures (ISPMs; IPPC 2017a). The ISPMs that deal most directly with forest pests include ISPM 15 (wood packaging materials, WPM; first adopted in 2002), ISPM-36 (plants for planting; 2012), ISPM 38 (seeds; 2017), ISPM 39 (wood; 2017), ISPM 40 (growing media; 2017), and ISPM 41 (used vehicles, machinery and equipment (VME); 2017) (IPPC 2017a; Table S2 in Supplementary material).

ISPM 15 lists specific guidelines for manufacturing, treating, and marking WPM (including dunnage). Since first adopted in 2002, ISPM 15 was substantially revised in 2006, 2009, and 2013 on topics such as debarking, maximum size of residual bark pieces, and new treatment options (IPPC 2017a). Setting limits on the maximum allowable size for residual bark pieces was based on field research in Europe and North America (Evans 2007; Haack and Petrice 2009). ISPM 15 has reduced the percentage of international shipments with live wood pests (Haack et al. 2014), but not eliminated the threat as evidenced by recent interceptions in WPM that have the ISPM 15 mark (Eyre et al. 2018; Wu et al. 2017). Such interceptions could indicate issues such as ineffective treatment standards, faulty equipment, or fraud (Haack et al. 2014). Interception records of insects associated with WPM also vary among countries, likely reflecting differences in trading partners and inspection protocols (Eyre et al. 2018). For example, the USA historically placed more emphasis on insects that infest living trees rather than dead trees or processed wood, which resulted in inspectors reporting true bark beetles 
(which often infest live trees) more often than ambrosia beetles, Anobiidae and Bostrichidae (which often infest dead trees or lumber) (Haack 2001, 2006). Nevertheless, even if only partially effective, ISPM 15 still likely provides large economic benefits by reducing the arrival rate of new forest pests (Leung et al. 2014).

The recently approved ISPM 39 addresses most types of wood other than WPM, but its implementation will likely require further legislation. For instance, wood chips are recommended to be less than $3 \mathrm{~cm}$ in at least two dimensions, but the ideal size will vary depending on the intended use (IPPC 2017a). Many countries require coniferous wood chips to be treated because they could contain pinewood nematode, Bursaphelenchus xylophilus (Parasitaphelenchidae; Allen et al. 2017; Hopf-Biziks et al. 2017), although similar regulations are mostly lacking for hardwood chips (Flø et al. 2014).

The other ISPMs (ISPM 36, 38, 40, and 41; IPPC 2017a) take more of a "systems approach" to pest reduction by integrating several independent phytosanitary measures that are applied throughout the production process of each commodity (Allen et al. 2017). The combination of multiple measures in a "systems approach" cumulatively reduces pest risk, often providing equivalent and more reliable alternatives than a single more expensive or limiting measure (FAO 2011). For example, ISPM 36 (plants for planting) deals with selecting production sites, pest management programs, training, packaging, transportation, internal audits, and record keeping of live plants for export (IPPC 2017a). A separate ISPM addresses seeds (ISPM 38), and another is being drafted for cut flowers and ornamental foliage, which are not classified as live plants and so are not included under ISPM 36 (IPPC 2017a, 2017b). Another example of a systems approach to pest reduction is ISPM 41 (used VME), which deals with topics such as cleaning and treatment of VME, prevention of contamination, facilities and waste disposal requirements, and verification procedures (IPPC 2017a).

Apart from the ISPMs, Regional Standards for Phytosanitary Measures (RSPMs) are also developed by Regional Plant Protection Organizations (RPPOs), such as the European and Mediterranean Plant Protection Organization (EPPO) or the North American Plant Protection Organization (NAPPO) (MacLeod et al. 2010). Most countries also have official agencies in charge of plant protection, which are called National Plant Protection Organizations (NPPOs) in the IPPC context (MacLeod et al. 2010). NPPOs can also set specific regulations to manage imports presenting risks to plant health. For example, New Zealand's phytosanitary standard for importation of nursery stock prescribes inspection on arrival, the presence of an import permit, labeling and a phytosanitary certificate, treatment with pesticides or hot water, and post-entry quarantine for up to 36 months (MPI 2017). These measures are stringent compared with the measures most other countries prescribe for importation of nursery stock (Eschen et al. 2015b). Similarly, in the case of wood chips imported into Great Britain, requirements vary depending on country of origin, tree species, and the presence of bark and may also require harvesting from pest-free areas (Forestry Commission 2015).

To mitigate the risk of movement of hitchhikers, soil, and other contaminants with shipments of empty sea containers, New Zealand implemented a bilateral sea container hygiene system with several Pacific Island nations. This entails storing containers on hard surfaces, cleaning all container surfaces, pest control and reducing pest habitat in port areas, auditing and other measures (MAF 2009). When fully implemented, the sea container hygiene system was found to be highly effective (MAF 2009). For instance, a 98.5\% reduction in ant contamination of imported containers was observed following 
implementation between 2002 and 2006 (Ashcroft et al. 2008). Despite the additional costs of these measures, the entire systems approach was considered to provide net financial benefits due to reduced inspection and treatment costs on arrival (MAF 2009).

\section{Concluding remarks}

International trade of goods and movements of people are largely responsible for introductions of non-native forest insects worldwide. Efforts to reduce these insect introductions have included the development of international standards for phytosanitary measures. For WPM, likely the most important pathway for bark and wood borers, recent global harmonization in phytosanitary treatments provided by ISPM 15 has been at least partially effective (Haack et al. 2014; Leung et al. 2014). In addition, the IPPC has recently approved several other ISPMs related to forest pests and is now finalizing standards for international movement of cut flowers and foliage (IPPC 2017b), which could prove useful to reduce transportation of tree foliage and sap feeders. However, despite increasing phytosanitary regulation to reduce unintentional pest movement (Haack et al. 2014, Eschen et al. 2015b), recent data have shown rates of new establishments still remain high (Boyd et al. 2013; Brockerhoff and Liebhold 2017). Factors that limit risk reduction come from increasing volumes of transported goods, variation in quarantine procedures between countries, and rapid changes in distribution networks (Leung et al. 2014; Eschen et al. 2015b; Ormsby and Brenton-Rule 2017). AQ4

Evaluation of future threats to forests by non-native tree pests is predominantly based on pest risk assessments of well-defined lists of species (e.g., Eschen et al. 2015b). However, the ongoing arrival of pests and the continuous emergence of new invasive pest species (Seebens et al. 2018), of which many were either unknown or harmless in their areas of origin, indicate that reliance on a limited number of species on pest lists is not entirely effective. Furthermore, there is an apparent mismatch between species intercepted during inspections at the border and those that established, which, in part, may be caused by disproportionate attention being given to regulated organisms (Eschen et al. 2015c). This suggests a better strategy is to evaluate risks at the pathway level. Rather than focussing mainly on particular pests that are perceived to be especially invasive and damaging, it is preferable to evaluate (and manage) pathways in a more generic fashion to address risks associated with all the species potentially transported that way (Hulme 2009, Boyd et al. 2013, Brockerhoff and Bulman 2014, Wingfield et al. 2015). Evaluating pathways should focus on (1) broader pest categories (e.g., wood borers or defoliating insects); (2) the most likely modes of transportation involved; and (3) medium-and long-term economic, environmental, or sociocultural impacts of pest establishment. Pathway-based analyses can be used with risk maps of pest introduction to improve deployment of early detection tools and mitigation strategies for non-native forest insects.

\section{Author contribution}

NM, DR, BPH, and RAH conceived, organized, and wrote the initial draft. EGB added details to all sections. RAH, NM, and DR prepared figures and tables. All authors reviewed and approved the manuscript.

\section{Acknowledgements}

This review is a component of the Special issue on "Invasive insect pests of forests and urban trees: pathways, early detection and management." We thank Lindsay Bulman (Scion), Mike Ormsby (New Zealand Ministry for Primary Industries, NZMPI) and Therese Poland (USDA Forest Service) for comments on an earlier draft of this paper, and Catherine Duthie (NZMPI) for personal communications. 
Compliance with ethical standards

Conflict of interest NM, DR, BPH, EGB, and RAH declare that they have no conflicts of interest.

Ethical approval This article does not contain any studies with human participants or animals performed by any of the authors.

\section{Electronic supplementary material}

Below is the link to the electronic supplementary material. Supplementary material 1 (DOCX $31 \mathrm{~kb})$

\section{References}

Allen EA, Humble LM (2002) Non-indigenous species introductions: a threat to Canada's forests and forest economy. Can J Plant Pathol 24:103-110

Allen E, Noseworthy M, Ormsby M (2017) Phytosanitary measures to reduce the movement of forest pests with the international trade of wood products. Biol Invasions 19:3365-3376

Anderson LG, Rocliffe S, Haddaway NR, Dunn AM (2015) The role of tourism and recreation in the spread of non-native species: a systematic review and meta-analysis. PLoS ONE 10:e140833

Areal FJ, Touza J, MacLeod A et al (2008) Integrating drivers influencing the detection of plant pests carried in the international cut flower trade. J Environ Manage 89:300-307

Ashcroft TT, Nendick D, O'Connor SM et al (2008) Managing the risk of invasive exotic ants establishing in New Zealand. In: Froud KJ, Popay AI, Zydenbos SM (eds) Surveillance for biosecurity: pre-border to pest management. The New Zealand Plant Protection Society, Hastings, pp 151-160

Auger-Rozenberg MA, Boivin T (2016) Invasive fruit, cone and seed insects in the Mediterranean basin. In: Payne TD, Lieutier F (eds) Insects and diseases of Mediterranean forest systems. Springer, Cham, pp 239-259

Aukema JE, McCullough DG, Holle BV et al (2010) Historical accumulation of nonindigenous forest pests in the continental United States. Bioscience 60:886-897

Bain J (1977) Overseas wood-and bark-boring insects intercepted at New Zealand ports. New Zealand Forest Service, Technical Paper 63. Rotorua

Battisti A, Stastny M, Buffo E, Larsson S (2006) A rapid altitudinal range expansion in the pine processionary moth produced by the 2003 climatic anomaly. Glob Change Biol 12:662-671

Beéche-Cisternas MA (2000) Riesgos cuarentenarios de insectos asociados a embalajes de madera y maderas de estiba de cargas de internacion en Chile. In: Proceedings: International conference on quarantine pests for the forestry sector and their effects on foreign trade, 27-28 Jun,

Concepcion 
Bisschop L (2012) Out of the woods: the illegal trade in tropical timber and a European trade hub. Glob Crime 13:191-212

Brasier CM (2008) The biosecurity threat to the UK and global environment from international trade in plants. Plant Path 57:792-808

Brockerhoff EG, Bulman L (2014) Biosecurity risks to New Zealand's plantation forests and the rationale for pathway risk management. NZ J For 59:3-8

Brockerhoff EG, Liebhold AM (2017) Ecology of forest insect invasions. Biol Invasions $19: 3141-3159$

Brockerhoff EG, Bain J, Kimberley MO, Knížek M (2006) Interception frequency of exotic bark and ambrosia beetles (Coleoptera: Scolytinae) and relationship with establishment in New Zealand and worldwide. Can J For Res 36:263-268

Brockerhoff EG, Bulman LS, Liebhold AM, Monge JP (2016) Role of sea containers in unintentional movement of invasive contaminating pests (so-called "hitchhikers"), and opportunities for mitigation measures, Food and Agricultural Organization of the United Nations, Rome, Italy. https://www.ippc.int/en/publications/82336/. Accessed 11 Feb 2018

Buck JH, Marshall JM (2009) Hitchhiking as a secondary dispersal pathway for adult emerald ash borer, Agrilus planipennis. Gt Lakes Entomol 41:197-199

Bulman LS (1999) Wood content in imported FCL containers. Unpublished report, commissioned by MAF, Wellington, Scion, Rotorua

AQ5

Cameron RS, Bates C, Johnson J (2008) Distribution and spread of laurel wilt disease in Georgia: 2006-08: survey and field observations. Georgia Forestry Commission. https://www.fs.fed.us /foresthealth/fhm/em/funded/09/so-em-08-02-report.pdf. Accessed 10 Feb 2018

Cappaert D, McCullough DG, Poland TM, Siegert NW (2005) Emerald ash borer in North America: a research and regulatory challenge. Am Entomol 51:152-165

Carroll AL, Taylor SW, Régnière J (2003) Effect of climate change on range expansion by the mountain pine beetle in British Columbia. Mountain Pine Beetle Symposium: Challenges and Solutions, 30-31 Oct, Kelowna, 223-232

Caton BP, Dobbs TT, Brodel CF (2006) Arrivals of hitchhiking insect pests on International Cargo Aircraft at Miami International Airport. Biol Invasions 8:765-785

Ciesla WM (1992) Introduction of bark beetles and wood borers into China in coniferous logs from North America. FAO Plant Prot Bull 40:154-158

Clarke JW, White MS, Araman PA (2001) Performance of pallet parts recovered from used wood pallets. For Prod J 51:1-8

Close RC, Moar NT, Tomlinson AI, Lowe AD (1978) Aerial dispersal of biological material from 
Australia to New Zealand. Int J Biometeorol 22:1-19

Cocquempot C (2007) Alien longhorned beetles (Coleoptera; Cerambycidae): original interceptions and introductions in Europe, mainly in France, and notes about recently imported species. Redia $89: 35-50$

Cocquempot C, Lindelöw $\AA$ (2010) Longhorn beetles (Coleoptera, Cerambycidae). BioRisk $4: 193-218$

Colunga-Garcia M, Haack RA, Magarey RD, Borchert DM (2013) Understanding trade pathways to target biosecurity surveillance. NeoBiota 18:103-118

Forestry Commission (2015) Importing woodchip requirements for landing regulated material into Great Britain. Forestry Commission, Edinburgh

Csóka G, Stone GN, Melika G (2017) Non-native gall-inducing insects on forest trees: a global review. Biol Invasions 19:3161-3181

Dodds KJ, Gilmore DW, Seybold SJ (2010) Assessing the threat posed by indigenous exotics: a case study of two North American bark beetle species. Ann Entomol Soc Am 103:39-49

Donovan BJ (1980) Interactions between native and introduced bees in New Zealand. NZ J Ecol $3: 104-116$

Eatough Jones M, Paine TD (2015) Effect of chipping and solarization on emergence and boring activity of a recently introduced ambrosia beetle (Euwallacea sp., Coleoptera: Curculionidae: Scolytinae) in southern California. J Econ Entomol 108:1852-1859

Eschen R, Grégoire JC, Hengeveld G et al (2015a) Trade patterns of the tree nursery trade in Europe and changes therein following findings of citrus longhorn beetle, Anoplophora chinensis Forster. Neobiota 26:1-20

Eschen R, Britton K, Brockerhoff $\mathrm{E}$ et al (2015b) International variation in phytosanitary legislation and regulations governing importation of plants for planting. Environ Sci Pol 51:228-237

Eschen R, Roques A, Santini A (2015c) Taxonomic dissimilarity in patterns of interception and establishment of alien arthropods, nematodes and pathogens affecting woody plants in Europe. Divers Distrib 21:36-45

Eschen R, Douma JC, Grégoire JC et al (2017) A risk categorisation and analysis of the geographic and temporal dynamics of the European import of plants for planting. Biol Invasions 19:3243-3257

Evans HF (2007) ISPM 15 treatments and residual bark: how much bark matters in relation to founder populations of bark and wood boring beetles. In: Evans H, Oszako T (eds) Alien invasive species and international trade. Forest Research Institute, Sêkocin Stary, pp 149-155

Exotic pets (2018) Macleays spectre stick insect. www.exotic-pets.co.uk/macleays-stickinsect.html. Accessed 19 Jan 2018 
Eyre D, Haack RA (2017) Invasive Cerambycid pests and biosecurity measures. In: Wang Q (ed) Cerambycidae of the world - biology and pest management. CRC Press, Boca Raton, pp 563-607

Eyre D, Macarthur R, Haack RA, Lu Y, Krehan H (2018) Variation in inspection efficacy by member states of wood packaging material entering the European Union. J Econ Entomol $11: 707-715$

FAO (2011) Guide to implementation of phytosanitary standards in forestry. FAO Forestry Paper 164, Food and Agriculture Organization of the United Nations, Rome

Flø D, Krokene P, Økland B (2014) Importing deciduous wood chips from North America to northern Europe-the risk of introducing bark-and wood-boring insects. Scand J For Res 29:77-89

Fox KJ (1978) The transoceanic migration of Lepidoptera to New Zealand - a history and a hypothesis on colonisation. NZ Entomol 6:368-380

Gadgil PD, Flint TN (1983) Assessment of the risk of introduction of exotic forest insects and diseases with imported tents. NZ J For 28:58-67

Gadgil PD, Bulman LS, Watson RN et al (2000) Significance to New Zealand forestry of contaminants on the external surfaces of shipping containers. NZ J For Sci 30:341-358

Garbelotto M, Gonthier P (2013) Biology, epidemiology, and control of Heterobasidion species worldwide. Annu Rev Phytopathol 51:39-59

GISTF (2017) Pathways of introduction. Georgia Invasive Species Task Force, Georgia Department of Agriculture Plant Protection Division, Atlanta, Georgia, USA. https://www.gainvasives.org/whatis/pathways-of-introduction/. Accessed 2 Feb 2018

Gray DR (2017) Risk analysis of the invasion pathway of the Asian gypsy moth: a known forest invader. Biol Invasions 19:3259-3272

Gu J, Braasch H, Burgermeister W, Zhang J (2006) Records of Bursaphelenchus spp. intercepted in imported packaging wood at Ningbo, China. For Pathol 36:323-333

Haack RA (2001) Intercepted Scolytidae (Coleoptera) at US ports of entry: 1985-2000. Integr Pest Manag Rev 6:253-282

Haack RA (2006) Exotic bark- and wood-boring Coleoptera in the United States: recent establishments and interceptions. Can J For Res 36:269-288

Haack RA (2017) Feeding biology of cerambycids. In: Wang Q (ed) Cerambycidae of the worldbiology and pest management. CRC Press, Boca Raton, pp 105-124

Haack RA, Petrice TR (2009) Bark- and wood-borer colonization of logs and lumber after heat treatment to ISPM 15 specifications: the role of residual bark. J Econ Entomol 102:1075-1084

Haack RA, Slansky F (1987) Nutritional ecology of wood-feeding Coleoptera, Lepidoptera, and Hymenoptera. In: Slansky F, Rodriguez JG (eds) Nutritional ecology of insects, mites, spiders, and 
related invertebrates. Wiley, New York, pp 449-486

Haack RA, Hérard F, Sun JH, Turgeon JJ (2010a) Managing invasive populations of Asian longhorned beetle and citrus longhorned beetle: a worldwide perspective. Annu Rev Entomol $55: 521-546$

Haack RA, Petrice TR, Wiedenhoft AC (2010b) Incidence of bark- and wood-boring insects in firewood: a survey at Michigan's Mackinac Bridge. J Econ Entomol 103:1682-1692

Haack RA, Britton KO, Brockerhoff EG et al (2014) Effectiveness of the international phytosanitary standard ISPM No. 15 on reducing wood borer infestation rates in wood packaging material entering the United States. PLoS ONE 9:e96611

Haack RA, Baranchikov Y, Bauer LS, Poland TM (2015) Emerald ash borer biology and invasion history. In: Van Driesche R, Duan J, Abell K, Bauer L, Gould J (eds) Biology and control of emerald ash borer. FHTET-2014-09, USDA Forest Service, Forest Health Technology Enterprise Team, Morgantown, pp 1-13

Harris AC (1988) A first record of the painted apple moth Teia anartoides (Lepidoptera: Lymantriidae) intercepted in New Zealand. NZ Entomol 11:68-70

Hennessey MK, Jeffers L, Nendick D et al (2014) Phytosanitary treatments. The handbook of plant biosecurity. Springer, Dordrecht, pp 269-308

Hoare RJB (2001) Adventive species of Lepidoptera recorded for the first time in New Zealand since 1988. NZ Entomol 24:23-47

Hoebeke ER, Carter ME (2003) Halyomorpha halys (Stál)(Heteroptera: Pentatomidae): a polyphagous plant pest from Asia newly detected in North America. Proc Entomol Soc Wash $105: 225-237$

Hoebeke ER, Haugen DA, Haack RA (2005) Sirex noctilio: discovery of a Palearctic siricid woodwasp in New York. News1 Mich Entomol Soc 50:24-25

Holzapfel EP, Harrell JC (1968) Transoceanic dispersal studies of insects. Pac Insects 10:115-153

Hopf-Biziks A, Schröder T, Schütz S (2017) Long-term survival and non-vector spread of the pinewood nematode, Bursaphelenchus xylophilus, via wood chips. For Pathol 47:e12340

Hulme PE (2009) Trade, transport and trouble: managing invasive species pathways in an era of globalization. J Appl Ecol 46:10-18

Hulme PE, Bacher S, Kenis M et al (2008) Grasping at the routes of biological invasions: a framework for integrating pathways into policy. J Appl Ecol 45:403-414

Humble LM, Allen EA (1999) Implications of nonindigenous introductions in forest ecosystems. Proceedings: Integrated management and dynamics of forest defoliating insects, 15-19 August, Newtown Square, 45-55 
Hurley BP, Garnas J, Wingfield MJ et al (2016) Increasing numbers and intercontinental spread of invasive insects on eucalypts. Biol Invasions 18:921-933

IATA (2017) IATA Annual Review 2016. International Air Transport Association, Montreal. http://www.iata.org/about/Documents/iata-annual-review-2016.pdf. Accessed 16 Jan 2018

ICAO (2016) Annual report of the ICAO Council: 2015-Appendices and Supplement. International Civil Aviation Organization, Montreal. https://www.icao.int/annual-report2015/Pages/appendices.aspx. Accessed 15 Jan 2018

IMO (2012) International shipping facts and figures information resources on trade, safety, security, environment. International Maritime Organization, London. http://www.imo.org /en/KnowledgeCentre/ShipsAndShippingFactsAndFigures /TheRoleandImportanceofInternationalShipping/Documents /International\%20Shipping\%20-\%20Facts\%20and\%20Figures.pdf. Accessed 07 Jan 2018

IPPC (2017a) Adopted Standards (ISPMs). https://www.ippc.int/en/core-activities/standards-setting /ispms/. Accessed 25 Jan 2018

IPPC (2017b) Draft ISPM international movement of cut flowers and foliage (first consultation), International Plant Protection Convention Secretariat, Food and Agricultural Organization of the United Nations, Rome. https://www.ippc.int/en/publications/84449/. Accessed 11 Feb 2018

ITF (2017) ITF transport outlook 2017. International Transport Forum, Organisation for Economic Co-operation and Development, Paris. http://dx.doi.org/10.1787/9789282108000-en. Accessed 10 Jan 2018

Jacobi WR, Goodrich BA, Cleaver CM (2011) Firewood transport by national and state park campers: a risk for native and exotic tree pest movement. Arboric Urban For 37:126-138

Jacobi WR, Hardin JG, Goodrich BA, Cleaver CM (2012) Retail firewood can transport live tree pests. J Econ Entomol 105:1645-1658

Jiang W, Searle S, Siddiqui S (2017) Analysis of the global wood-chip trade's response to renewable energy policies using a spatial price equilibrium model. Biofuels Bioprod Biorefin $11: 505-520$

Kenis M, Hurley BP, Hajek AE, Cock MJW (2017) Classical biological control of insect pests of trees: facts and figures. Biol Invasions 19:3401-3417

Kiesz A (2003) New exotic wood-boring pests found in U.S. https://sdda.sd.gov/legacydocs /Forestry/educational-information/PDF/treetalkdecember26.pdf. Accessed 28 Jan 2018

Kirkendall LR, Faccoli M (2010) Bark beetles and pinhole borers (Curculionidae, Scolytinae, Platypodinae) alien to Europe. ZooKeys 56:227-251 
United States of unprocessed Pinus logs and chips from Australia. General Technical Report FPL-GTR-137, USDA, Forest Service, Madison

Kopinga J, Moraal LG, Verwer CC, Clerkx APPM (2010) Phytosanitary risks of wood chips. Alterra report 2059, Alterra, Wageningen, pp 88

Kovacs KF, Mercader RJ, Haight RG et al (2011) The influence of satellite populations of emerald ash borer on projected economic costs in US communities, 2010-2020. J Environ Manage 92:2170-2181

Kumschick S, Devenish A, Kenis M et al (2016) Intentionally introduced terrestrial invertebrates: patterns, risks, and options for management. Biol Invasions 18:1077-1088

Lee W, Hwang JH, Lee JH, Hong KJ (2017) Interception of weevils on cut flowers from South Africa by Korea plant quarantine. J Asia Pac Biodivers 10:527-531

Leung B, Springborn MR, Turner JA, Brockerhoff EG (2014) Pathway-level risk analysis: the net present value of an invasive species policy in the US. Front Ecol Environ 12:273-279

Levine JM, D'Antonio CM (2003) Forecasting biological invasions with increasing international trade. Conserv Biol 17:322-326

Liebhold AM, Work TT, McCullough DG, Cavey JF (2006) Airline baggage as a pathway for alien insect species entering the United States. Am Entomol 52:48-54

Liebhold AM, Brockerhoff EG, Garrett LJ, Parke JL, Britton KO (2012) Live plant imports: the major pathway for forest insect and pathogen invasions of the US. Front Ecol Environ 10:135-143

Liebhold AM, Yamanaka T, Roques A et al (2016) Global compositional variation among native and non-native regional insect assemblages emphasizes the importance of pathways. Biol Invasions 18:893-905

Liebhold AM, Brockerhoff EG, Kalisz S et al (2017) Biological invasions in forest ecosystems. Biol Invasions 19:3437-3458

MacLeod A, Pautasso M, Jeger MJ, Haines-Young R (2010) Evolution of the international regulation of plant pests and challenges for future plant health. Food Secur 2:49-70

MAF (2003) Sea container review New Zealand. MAF Discussion Paper No: 35. Ministry of Agriculture and Forestry, Wellington

MAF (2006) Monitoring research and pathways review: Sea containers. Ministry of Agriculture and Forestry, Wellington

MAF (2009) Cost benefit analysis: Application of sea container hygiene systems in Papua New Guinea. Samoa and the Solomon Islands, Ministry of Agriculture and Forestry, Wellington 
Maier CT (2017) Cerambycidae (Coleoptera) accidentally introduced into Connecticut from China or from other areas in the United States. Proc Entomol Soc Wash 119:423-429

Mayer F, Piel F, Cassel-Lundhagen A et al (2015) Comparative multilocus phylogeography of two Palaearctic spruce bark beetles: influence of contrasting ecological strategies on genetic variations. Mol Ecol 24:1292-1310

McClure MS (1990) Role of wind, birds, deer, and humans in the dispersal of hemlock woolly adelgid (Homoptera: Adelgidae). Environ Entomol 19:36-43

McCullough DG, Work TT, Cavey JF et al (2006) Interceptions of nonindigenous plant pests at US ports of entry and border crossings over a 17-year period. Biol Invasions 8:611-630

McCullough DG, Poland TM, Cappaert D et al (2007) Effects of chipping, grinding, and heat on survival of emerald ash borer, Agrilus planipennis (Coleoptera: Buprestidae), in chips. J Econ Entomol 100:1304-1315

Meissner H, Lemay A, Bertone C (2009) Evaluation of pathways for exotic plant pest movement into and within the greater Caribbean Region. Caribbean Invasive Species Working Group and USDA APHIS Center for Plant Health Science and Technology, Raleigh. https://naldc.nal.usda.gov/download/32155/PDF. Accessed 11 Feb 2018

Migliorini D, Ghelardini L, Tondini E, Luchi N, Santini A (2015) The potential of symptomless potted plants for carrying invasive soilborne plant pathogens. Divers Distrib 21:1218-1229

Morgan FD (1967) Ips grandicollis in South Australia. Aust For 31:137-155

Morrison A, Sweeney J, Hughes C, Johns RC (2017) Hitching a ride: firewood as a potential pathway for range expansion of an exotic beech leaf-mining weevil, Orchestes fagi (Coleoptera: Curculionidae). Can Entomol 149:129-137

MPI (2013) Passenger Compliance Monitoring Report 2013. Ministry for Primary Industries, Wellington. https://www.mpi.govt.nz/dmsdocument/3977-mpi-passenger-compliance-monitoringreport-auckland-christchurch-and-wellington-international-airports-may-to-June-2013. Accessed 12 Jan 2018

MPI (2017) Ministry for Primary Industries Standard 155.02.06 Importation of Nursery Stock. Ministry for Primary Industries, Wellington. https://www.mpi.govt.nz/dmsdocument/1152nursery-stock-import-health-standard. Accessed 9 Feb 2018

Newfield MJ (2008) Pest risk analysis for six moth species: lessons for the biosecurity system on managing hitchhiker organisms. New Zealand Ministry of Agriculture and Forestry, Wellington

Nielsen J, Rees D, Styles S, Hickey L (2013) An update on Australia's use of remote sensing to predict risk maritime pathways for gypsy moths (Lymantria spp., Lepidoptera: Erebidae) -operational results for 2011-2013. International Forest Quarantine Research Group Conference, 28 Oct - 1 Nov, Qingdao, 1-12 
Niinemets U, Peñuelas J (2008) Gardening and urban landscaping: significant players in global change. Trends Plant Sci 13:60-65

Ormsby M, Brenton-Rule E (2017) A review of global instruments to combat invasive alien species in forestry. Biol Invasions 19:3355-3364

Rassati D, Lieutier F, Faccoli M (2016) Alien wood-boring beetles in Mediterranean regions. In: Payne TD, Lieutier F (eds) Insects and diseases of Mediterranean forest systems. Springer, Cham, pp 293-327

Rassati D, Haack RA, Knížek M, Faccoli M (2018) National trade can drive range expansion of bark- and wood-boring beetles. J Econ Entomol 111:260-268

Ridley GS, Bain J, Bulman LS, Dick MA, Kay MK (2000) Threats to New Zealand's indigenous forests from exotic pathogens and pests. Sci Conserv 142:1-67

Rieske LK (2007) Success of an exotic gallmaker, Dryocosmus kuriphilus, on chestnut in the USA: a historical account. EPPO Bull 37:172-174

Roques A (2010) Alien forest insects in a warmer world and a globalised economy: impacts of changes in trade, tourism and climate on forest biosecurity. NZ J For Sci 40(Suppl):S77-S94

Roques A, Auger-Rozenberg MA (2006) Tentative analysis of the interceptions of non-indigenous organisms in Europe during 1995-2004. EPPO Bull 36:490-496

Saccaggi DL, Pieterse W (2013) Intercepting aliens: insects and mites on budwood imported to South Africa. J Econ Entomol 106:1179-1189

Saccaggi DL, Karsten M, Robertson MP et al (2016) Methods and approaches for the management of arthropod border incursions. Biol Invasions 18:1057-1075

Sánchez-Salinas PF (2007) Evaluación de la efectividad de la implementación de la NIMF 15 para embalajes de madera de importacin en la barrera fitosanitaria internacional Puerto San Antonio, Región de Valparaíso. Thesis, University of Talca, Chile

Schaefer PW, Strothkamp KG (2014) Mass flights of Lymantria dispar japonica and Lymantria mathura (Erebidae: Lymantriinae) to commercial lighting, with notes on female viability and fecundity. J Lepid Soc 68:124-129

Seebens H, Blackburn TM, Dyer EE et al (2017) No saturation in the accumulation of alien species worldwide. Nat Commun 8:14435

Seebens H, Blackburn TM, Dyer EE et al (2018) Global rise in emerging alien species results from increased accessibility of new source pools. PNAS. https://doi.org/10.1073/pnas.1719429115

Siitonen J (1990) Potential forest pest beetles conveyed to Finland on timber imported from the Soviet Union. Silva Fenn 24:315-321

Smith RM, Baker RH, Malumphy CP et al (2007) Recent non-native invertebrate plant pest establishments in Great Britain: origins, pathways, and trends. Agric For Entomol 9:307-326 
Stanaway MA, Zalucki MP, Gillespie PS, Rodriguez CM, Maynard GV (2001) Pest risk assessment of insects in sea cargo containers. Aust J Entomol 40:180-192

Tkacz BM (2002) Pest risks associated with importing wood to the United States. Can J Plant Pathol 24:111-116

Todd JJ, Horwitz PHJ (1990) Spreading insects through firewood collection in Tasmania. Aust For 53:154-159

Toy SJ, Newfield MJ (2010) The accidental introduction of invasive animals as hitchhikers through inanimate pathways: a New Zealand perspective. Revue scientifique et technique (International Office of Epizootics) 29:123-133

Turgeon JJ, Orr M, Grant C, Wu Y, Gasman B (2015) Decade-old satellite infestation of Anoplophora glabripennis Motschulsky (Coleoptera: Cerambycidae) found in Ontario, Canada outside regulated area of founder population. Coleopt Bull 69:674-678

UNCTAD (2017) Review of Maritime Transport 2016. United Nations Conference on Trade and Development, New York. http://unctad.org/en/PublicationsLibrary/rmt2016_en.pdf. Accessed 16 Jan 2018

USDA APHIS (2010) Risk assessment of the movement of firewood within the United States. USDA, Animal and Plant Health Inspection Service, Raleigh. https://www.aphis.usda.gov /import_export/plants/plant_imports/firewood/firewood_pathway_assessment.pdf. Accessed 11 Feb 2018

van der Gaag DJ, Leeuwen GCM, Loomans AJM, Potting RPJ, Verhoeven JTJ (2017) Prioritizing risks for plant health in the Netherlands: a method to rank pests according to their probability of introduction. EPPO Bull 47:69-78

Venette RC, Davis EE, DaCosta M, Heisler H, Larson M (2003) Mini-risk assessment: light brown apple moth, Epiphyas postvittana (Walker) (Lepidoptera: Tortricidae). USDA APHIS. http://www.aphis.usda.gov/planthealth/plantpestinfo/pestdetection/downloads /pra/epostvittanapra.pdf. Accessed 03 Feb 2018

Westphal MI, Browne M, MacKinnon K, Noble I (2008) The link between international trade and the global distribution of invasive alien species. Biol Invasions 10:391-398

Wingfield MJ, Brockerhoff EG, Wingfield BD, Slippers B (2015) Planted forest health: the need for a global strategy. Science 349:832-836

Withers TM (2001) Colonization of eucalypts in New Zealand by Australian insects. Austral Ecol $26: 467-476$

Wu Y, Trepanowski NF, Molongoski JJ, Reagel PF et al (2017) Identification of wood-boring beetles (Cerambycidae and Buprestidae) intercepted in trade-associated solid wood packaging material using DNA barcoding and morphology. Sci Rep 7:40316 
Yan Z, Sun J, Owen D, Zhang Z (2005) The red turpentine beetle, Dendroctonus valens LeConte (Scolytidae): an exotic invasive pest of pine in China. Biodivers Conserv 14:1735-1760

Zlotina MA, Mastro VC, Elkinton JS, Leonard DE (1999) Dispersal tendencies of neonate larvae of Lymantria mathura and the Asian form of Lymantria dispar (Lepidoptera: Lymantriidae). Environ Entomol 28:240-245

Boyd IL, Freer-Smith PH, Gilligan CA, Godfray HCJ (2013) The consequence of tree pests and diseases for ecosystem services. Science 342:1235773

Haack RA, Keena MA, Eyre D (2017) Life history and population dynamics of cerambycids. In: Wang Q (ed) Cerambycidae of the world—biology and pest management. CRC Press, Boca Raton, pp 71-103. 